\title{
Analysis of the Factors Affecting the Efficiency of Regional Tourism Growth in China
}

\author{
Jinhua Zhang \\ Economics and Management School of Beihua University, Jilin 132013, China \\ 418470072@qq.com
}

\begin{abstract}
Keywords: Regional ourism; Growth efficiency; Nonparametric malmquist productivity index, Panel cointegration mode
\end{abstract}

\begin{abstract}
Growth in the continuous improvement of the efficiency for modern tourism industry competition, competitive advantage, to resist external risks, improve business performance, to achieve the maximum benefit, has important significance. The non-parameter Malmquist productivity index decomposition method to measure and analyze the China 31 by province based autonomous regions and municipalities directly under the central government in $2005-2015$ years of change and efficiency technology progress. And combining with the panel counteraction model to analyze the financial conditions, geographic conditions, asset size effect of tourism, travel agency factor growth efficiency of regional tourism industry.
\end{abstract}

\section{Problems Raised}

The tourism industry has a certain level of growth efficiency and technological progress in the growth process is the core competitiveness of the tourism industry and an important form. Regional tourism growth efficiency reflects the utilization of inputs to the tourism industry in the area of tourism growth. In the process of regional tourism growth performance directly determines the level of the status of each region in the increasingly fierce competition environment. Continuously improve the tourism growth performance is the regional tourism industry each competition, to seek the competitive advantage, to resist external risks, improve business performance, key to achieve maximum benefits. So at this stage, for China's tourism industry, how to further improve the growth performance, take the development of suitable model is an urgent need to solve the problems. This paper uses 31 Chinese each province, autonomous region and municipality directly under the central government in 2005 -2015 years of relevant. Travel industry data, using the non parameter Malmquist productivity index decomposition method to calculate the tourism industry in various regions of the growth efficiency and technical progress. Based on nonparametric panel cointegration model to analyze the related factors affecting the growth efficiency of regional tourism industry.

\section{Regional Tourism Grow the Efficiency and Technological Progress}

Research Object Selection and Variable Selection. Based on the existing research results, this paper selects the domestic tourism revenue $\left(Y_{1}\right)$ and international tourism revenue $\left(Y_{2}\right)$ as the output measure of tourism. The paper also selected tourism resources $\left(X_{1}\right)$, tourist service facilities $\left(X_{2}\right)$ and tourism practitioners $\left(X_{3}\right)$ in the 3 indicators to measure the area in the tourism industry. The tourism resources is reflected by the ratio of excellent tourism city and the province and above the county level city. In order to fully reflect the characteristics of the index of regional tourism China growth efficiency, this paper selects 31 China Province, autonomous region and municipality directly under the central government as a section of comparison, the sample length for 2005 -2015. Data sources: "China Tourism Statistical Yearbook" and "China Statistical Yearbook".

Regional Tourism Growth Efficiency and Prediction of Technical Progress. Table 1 is the 31 province of China, autonomous regions and municipalities since 2005 the growth efficiency and technical progress of descriptive statistics from table 1 . The calculation results can be seen that the 
overall efficiency of regional tourism Chinese growth present an evolution of the first decline after rising trend between regions. The tourism growth efficiency of the standard deviation reflects the change in overall regional tourism growth efficiency gap. The results show that during 2005-2015 years, the regional tourism growth efficiency gap is increasing.

Table 1 ( 2005-2015 year) The efficiency change of tourism in China and descriptive statistical analysis of technological progress

\begin{tabular}{|l|l|l|l|l|}
\hline \multirow{2}{*}{ year } & \multicolumn{2}{|l|}{ Growth efficiency } & \multicolumn{2}{l|}{} \\
\cline { 2 - 5 } & mean value & $\begin{array}{l}\text { standard } \\
\text { deviation }\end{array}$ & mean value & $\begin{array}{l}\text { standard } \\
\text { deviation }\end{array}$ \\
\hline 2005year & 0.5622 & 0.2557 & 1.6786 & 0.6972 \\
\hline 2006year & 0.5290 & 0.2690 & 2.0924 & 0.7655 \\
\hline 2007year & 0.6237 & 0.2705 & 2.4408 & 0.8111 \\
\hline 2008year & 0.5132 & 0.2752 & 2.4444 & 0.8177 \\
\hline 2009year & 0.5452 & 0.2723 & 2.5428 & 0.8716 \\
\hline 2010year & 0.6059 & 0.3052 & 2.3277 & 0.8572 \\
\hline 2011year & 0.6373 & 0.3103 & 2.7417 & 0.9932 \\
\hline 2012year & 0.6947 & 0.3316 & 3.0673 & 1.1049 \\
\hline 2013year & 0.7035 & 0.3352 & 3.3981 & 1.2311 \\
\hline 2014year & 0.7329 & 0.3578 & 3.6956 & 1.3632 \\
\hline 2015year & 0.7429 & 0.3707 & 3.6956 & 1.3632 \\
\hline
\end{tabular}

In the process of technological progress, this paper analyzes the situation of tourism growth in various regions of China, The focus is on the input output frontier. Regional tourism growth China average level of technological progress, showing the overall upward trend. Chinese in tourism development process of overall technological progress, technical differences between the level of China regional tourism is growing, There is no change in the level of regional tourism industry

\section{An Empirical Analysis of the Factors Affecting the Growth Efficiency of Regional Tourism}

The Structure Model of Influencing Factors of Tourism Growth Efficiency. According to the previous research work and considering the actual situation of the development of China tourism industry, this paper mainly analyzes the financial conditions, geographic conditions, asset scale tourism, the four factors affecting the efficiency of travel to the regional tourism industry. This article selects the per capita GDP reflect the measured area of the financial situation, regional endowment and geographic conditions the individual effect of panel data model in the control area of tourism efficiency, reflects the use of the tourism industry in various regions of the fixed assets investment of tourism development around the capital input, select the number of travel agencies as a reflection of regional tourism facilities.

Based on the above considerations, the panel cointegration equation is constructed:

$$
e f f_{i t}=\alpha_{i}+\beta_{1} p g d p_{i t}+\beta_{2} \text { fixa }+\beta_{3} \text { rrag }_{i t}+\varepsilon_{i t}
$$

The ( eff $f_{i t}$ )represents $(i)$ area at the time $(t)$ of the tourism growth efficiency; $\left(\alpha_{i}\right)$ is the introduction of fixed effects, influence factors of resources to reflect the area of tourism growth efficiency; $\left(p g d p_{i t}\right)$ represents( $i$ )area per capita GDP in time $(t)$, to reflect the financial strength; ( fixa $\left._{i t}\right)$ ixed assets in the region is reflected in the time $(t)$. In the process of tourism development of the asset size of the area; $\left(\operatorname{trag}_{i t}\right)$ in the total area Chinese travel time $(t)$, reflect the region's tourism development in the tourism hardware. From each coefficient meaning, model (5) shows the influence mechanism of tourism industry efficiency model. (5) effect of growth efficiency to reflect the regional tourism process, it may still exist missing variables model set problems. If the omission 
of model variables often lead to endogeneity problem model, related statistical inference. In this paper, the panel dynamic least squares (DOLS) estimation method is used to solve the endogeneity problem of model (5)

Panel Cointegration Test and DOLS Estimation of Model. Before the panel cointegration analysis, we must first panel unit root test on the relevant variables. Based on the panel data of $\left({ }^{e f f} f_{i t}\right) 、\left({ }^{p g d p_{i t}}\right) 、\left({ }^{f i x a_{i t}}\right) 、\left({ }^{\text {rag }_{i t}}\right)$ independent variables, section panel IPS test and relevant section panel combined with $\mathrm{P}$ value test. Table 2 gives the level of sequence and panel data unit root first-order difference sequence of test results.

Table 2 variable ompany unit root test

\begin{tabular}{|c|c|c|c|c|c|c|c|c|}
\hline variable & eff & $\Delta e f f$ & $p g d p$ & $\Delta p g d p$ & fixa & $\Delta$ fixa & trag & $\Delta$ trag \\
\hline $\begin{array}{ll}t_{I P S} & \text { Test } \\
\text { statistic } & \end{array}$ & $\begin{array}{l}0.384 \\
1\end{array}$ & $\begin{array}{l}-3.645 \\
0\end{array}$ & 0.2203 & $\begin{array}{l}-1.869 \\
4\end{array}$ & 0.0201 & $\begin{array}{l}-2.771 \\
3\end{array}$ & 0.0707 & $\begin{array}{l}-5.185 \\
1\end{array}$ \\
\hline$P$ value & $\begin{array}{l}0.352 \\
0\end{array}$ & 0.0000 & 0.4129 & 0.0314 & 0.4918 & 0.0029 & 0.4718 & 0.0000 \\
\hline $\begin{array}{l}\text { Joint } \mathrm{P} \text { value } \\
\text { test }\end{array}$ & $\begin{array}{l}6.330 \\
8\end{array}$ & $\begin{array}{l}32.983 \\
7\end{array}$ & 6.5245 & $\begin{array}{l}42.067 \\
4\end{array}$ & 5.8473 & $\begin{array}{l}33.876 \\
2\end{array}$ & 7.8372 & $\begin{array}{l}42.382 \\
1\end{array}$ \\
\hline$P$ value & $\begin{array}{l}0.141 \\
7\end{array}$ & 0.0118 & 0.1392 & 0.0001 & 0.1704 & 0.0204 & 0.3076 & 0.0011 \\
\hline
\end{tabular}

From table 2, Panel number of four variables, Is the conclusion of the I (1) process.

This paper selected 31 provinces, autonomous regions and municipalities directly under the central panel data has great heterogeneity in the cross section, which intends to use the Westerlund (2006) cointegration test panel proposed the non parameter testing method of variance ratio test for the above four variables. The test results are shown in Table 3

Table 3 the results of panel variable co integration test

\begin{tabular}{|l|l|l|l|}
\hline$V R_{G}$ & $P$ value & $V R_{P}$ & $P$ value \\
\hline 0.9452 & 0.0023 & 0.8635 & 0.0031 \\
& & & \\
\hline
\end{tabular}

Table 3 shows that the growth rate of tourism, per capita GDP, fixed assets, the number of travel agencies, There is a long-term stable cointegration relationship between the four variables. The final results of further DOLS estimation are shown in Table 4

Table 4 Estimation results of co integration vector DOLS

\begin{tabular}{|l|l|l|l|l|l|l|l|l|}
\hline region & $\hat{\alpha}_{i}$ & $\begin{array}{l}p \text { test } \\
\text { value }\end{array}$ & $\hat{\beta}_{1 i}$ & $\begin{array}{l}P \text { test } \\
\text { value }\end{array}$ & $\hat{\beta}_{2 i}$ & $\begin{array}{l}p \text { test } \\
\text { value }\end{array}$ & $\hat{\beta}_{3 i}$ & $\begin{array}{l}p \text { test } \\
\text { value }\end{array}$ \\
\hline Beijing & 0.0601 & 0.0125 & 0.0112 & 0.0000 & 0.0550 & 0.0000 & 0.0344 & 0.0303 \\
\hline Tianjin & 0.0456 & 0.0220 & 0.0269 & 0.0040 & 0.0896 & 0.0131 & -0.0451 & 0.0121 \\
\hline Hebei & 0.0908 & 0.0156 & 0.0249 & 0.0000 & 0.0380 & 0.0305 & 0.0244 & 0.0215 \\
\hline Shanxi & 0.0892 & 0.0320 & 0.0312 & 0.0089 & 0.0307 & 0.0175 & -0.0974 & 0.0062 \\
\hline Guizhou & 0.0621 & 0.0186 & 0.2858 & 0.0295 & 0.0456 & 0.0089 & -0.0719 & 0.0201 \\
\hline Yunna & 0.0352 & 0.0425 & 0.3627 & 0.0015 & 0.0809 & 0.0418 & 0.0912 & 0.0384 \\
\hline Xizang & 0.0559 & 0.0351 & 0.2883 & 0.0442 & 0.0661 & 0.0479 & 0.0421 & 0.0550 \\
\hline Shanxi & 0.0742 & 0.0025 & 0.3352 & 0.0009 & 0.0216 & 0.0038 & 0.0238 & 0.0009 \\
\hline Gansu & 0.0268 & 0.0031 & 0.3124 & 0.0000 & 0.0295 & 0.0265 & 0.0215 & 0.0479 \\
\hline Qinghai & 0.0325 & 0.0504 & 0.3055 & 0.0007 & 0.0450 & 0.0431 & 0.0315 & 0.0406 \\
\hline Ningxia & 0.0526 & 0.0301 & 0.3383 & 0.0102 & 0.0574 & 0.0406 & 0.0407 & 0.0085 \\
\hline Xinjiang & 0.0421 & 0.0000 & 0.2273 & 0.0006 & 0.0440 & 0.0026 & 0.0195 & 0.0084 \\
\hline
\end{tabular}


Table 4 gives the model (5) the DOLS estimation results. In the long term, although not all of the estimated coefficient is significant, but the per capita GDP, fixed assets, a positive impact on the overall number of travel agencies or the tourism industry to improve the efficiency. $\left(\hat{\alpha}_{i}\right)$ reflect the influence is in a different area of endowments and geographical conditions on the growth of the tourism industry efficiency. In Hebei, and Shanxi, the most obvious advantage of the strongest, the tourism growth efficiency. , Shanxi also has a relatively strong geographical advantage. The coefficient $\left(\hat{\beta}_{1 i}\right)$ reflects the regional financial support effect on Regional Tourism efficiency the coefficients from the estimated results, the regional financial support for the regional tourism industry a greater impact on the efficiency of this empirical research. The theoretical analysis results and the front line. The regional financial support provided by the landscape, traffic and environment construction of hardware is supported Supporting the development of tourism industry is an important foundation

So this paper argues that the current regional financial support is limited, in order to regional tourism development, should as much as possible, to provide funds for the development of the tourism industry, the realization of financial support of tourism development, tourism development, regional economic development feedback ". The coefficient $\left(\hat{\beta}_{2 i}\right)$ reflects the impact of fixed assets on Tourism efficiency. The estimation results show that various regions of the country the amount of fixed assets of tourism efficiency are very significant, especially in the western region. The impact of asset size of tourist production efficiency is very significant. The coefficient $\left(\hat{\beta}_{3 i}\right)$ directly reflects the effect of number of travel agencies on the tourism industry efficiency. Can see from the result in some areas the total number of travel agencies and tourism production efficiency showed a negative correlation between the common sense in the face of the travel agency for tourist production efficiency have a positive impact on the development of the tourism industry. It shows that There are problems with the operation of China's travel agencies, This is in the last 10 years, China's travel agencies, large-scale, low quality, loose management, the development of a direct relationship. So this paper thinks regulators of tourism industry in various regions to establish a set of effective supervision system, strengthen all aspects of the management of travel agencies, the implementation of information transparency, improve information symmetry in both sides of the supply and demand of tourism market, prevent the travel agency market appeared in the "lemon market" phenomenon.

\section{Reference}

[1] Im K., Pesaran, H., Shin, Y., 1997, “Testing for unit roots in heterogeneous panels," Manuscript, Department of Applied Economics, University of Cambridge.

[2] Im K.S., M.H.Pesaran and Y.Shin, 2003, "Testing for Unit Roots in Heterogeneous Panels," Journal of Econometrics, Vol.115, pp: 53-74.

[3] Maddala, G. S. and Wu, S., 1999, “A comparative study of unir roots with panel data and a new simple test," Oxford Bulletin of Economics and statistics, Special Issue, pp: 631-652.

[4] McCoskey, S., and C. Kao, 1998, "A Residual-Based Test of the Null of Cointegration in Panel Data," Econometric Reviews, No. 17, pp: 57-84.

[5] Westerlund .J, 2005, "A panel CUSUM Test of the null of cointegration," Oxford Bulletin of Economics and Statistics, 62, pp: 231-262.

[6] Westerlund .J, 2008, "Panel Cointegration Tests of the Fisher Effect," Journal of Applied Econometrics, 23, pp: 193-233.

[7] Wang Kai, Yi Jing, A study on the relationship between tourism industrial agglomeration and industrial efficiency in China [J] human geography, 2016, 08

[8] Angela Baby, Wang Qin,. Study on the growth efficiency and influencing factors of international inbound tourism $[\mathrm{J}]$.Economic system reform, 2016, 05

[9] Zhi Hui an, The spatial and temporal evolution of tourism efficiency and its influencing factors in China[D] .yunnan normal university, 2016, 05 
[10] He Junyang, he Ling, Liu Zhongyan, An empirical analysis on the operation efficiency and influencing factors of Provincial Tourism [J] Search.2015, 04

[11] Libianfang, Analysis on the efficiency difference of regional tourism industry in China [D] Northwest Normal University,2015, 05

[12] Jinhua Chang, A study on the dynamic evolution of Chinese tourism efficiency and productivity[M] Jilin People's Press2014, 07 